\title{
Problems in Commercial Hunting Systems: South Dakota and Texas Compared ${ }^{1}$
}

\section{KIETH E. SEVERSON AND F. ROBERT GARTNER}

Range Scientist, Rocky Mountain Forest and Range Experiment Station, 2 and Associate Professor of Animal Science (Range Ecology), Agricultural Research and Extension Center, South Dakota State University, Rapid City.

\section{Highlight}

The practice of charging hunters a fee to use private lands, although extensive and well-established in Texas, is relatively new in western South Dakota. Problems caused by, and the possibilities for, commercial hunting systems are compared between these States. Discussion centers around four factors: state hunting regulations, proximity of public lands, hunter demand and the game crop, and attitudes of landowners and hunters.

The practice of charging hunters a fee to use private lands, although relatively new, is becoming increasingly popular with western South Dakota landowners. Leasing systems of this kind have been in use in other parts of the country for many years. Commerical hunting began in Texas in the early 1920's (Teer and Forrest, 1968) and today it is virtually impossible to hunt any species of big game and many small game species in that State without paying a "trespass," "hunting," or "landuse" fee.

Like other land management problems, fee hunting policies in one State may not be applicable in another. However, comparisons of specific problems as well as basic

\footnotetext{
${ }^{1}$ Approved by the director of the South Dakota Agricultural Experiment Station as Journal Series No. 1037. Received December 3, 1971. The authors express their appreciation to the officers and members of Dakota Safaris, Inc. for their cooperation in supplying information used in this publication.

${ }^{2}$ Forest Service, U.S. Department of Agriculture. Central headquarters maintained in cooperation with Colorado State University at Fort Collins. Research reported here was conducted in cooperation with the South Dakota School of Mines and Technology at Rapid City.
}

principles between States may help landowners, sportsmen, and professional land managers develop guidelines for their particular situations. The purpose of this paper is to compare the circumstances which dictate commercial hunting systcm policy in South Dakota with those affecting similar programs in Texas. We do not intend to unequivocally condemn or condone commercial hunting systems. However, wc do believe a system designed not only for optimum economic return, but also with the needs of the public and the total range and wildlife resource in mind, will result in an increased awareness of the importance of proper management. Hopefully, this awareness will result in added interest and incentive to maintain or develop better land management programs.

We previously described one kind of a leasing system designed by Dakota Safaris for deer hunting in western South Dakota (Gartner and Severson, 1972). Although this is considered an economically successful operation, it is not without some biological, social and legal problems.

The success or failure of a commercial hunting operation can be attributed to a number of factors, including State hunting regulations, proximity of public lands, hunter demand and the game crop, and attitudes of landowners and hunters. These factors will be compared in their effects on fee hunting in South Dakota and Texas.

\section{Hunting Regulations}

State hunting regulations that can influence commercial hunting systems include the total number of licenses available, the number made available to nonresidents, the length of the season, and bag limits.

South Dakota has three basic deer hunting areas. The Black Hills area has an unlimited number of licenses available (for both residents and nonresidents) and the season normally lasts 30 days. However, most of this area is public land administered by the Forest Service of the U.S. Department of Agriculture. Private lands are intcrspersed throughout the area, but most are too small to provide trespass privileges for deer hunting.

The East River Area (east of the Missouri River) was limitcd to 9,500 resident licenses for a 9-day season in 1970. While virtually all private land, most holdings are in farms too small to provide for an adequate fee hunting system.

Most of the fee hunting systems in South Dakota are being developed in the West River Areathat rangeland between the Missouri River and the Black Hills excluding Indian lands. Here, the landholdings are in larger ranches, many of which have potential for some kind of leasing system. In 1970, 11,400 licenses were distributed for a 9-day season among 20 units (essentially by counties). Nonresidents were allowed $4 \%$ of the licenses in each unit, compared to $8 \%$ in previous years.

The total number of licenses issued in each unit probably would not restrict a fee hunting system, but ranchers operating a hunting system in States where license quotas are in effect should be constantly aware that these quotas are subject to fluctuations. Below-average quota allotments could result in too few licenses to make a hunting system profitable, particularly if several such operations exist within a single management unit.

Limitations on nonresident quotas can adversely affect fee hunting systems, especially those tailored for the affluent hunter. South Dakota ranked 35th in per capita income in a 1969 survey (U.S. Bureau of the Census, 1970). Only 35\% of 
the 56 hunters handled by Dakota Safaris in 1970 were South Dakota residents (Marion Robinson, personal communication). Primary lands controlled by Dakota Safaris are located in two hunting units with a 1970 combined total of 3,000 licenses. Thus they had a potential of 120 licenses for nonresident hunters. In 1971, because of changes in hunting unit boundaries, only 900 total licenses were available on these Dakota Safaris lands, 36 of which went to nonresidents. If many ranchers initiated expensive, all-services, hunting systems under these restrictions, there would be too few nonresident licenses to make such systems economically feasible for each rancher. Other less expensive hunting systems, with fewer services, would have to be developed in order to attract hunters from lower income groups.

The length of the hunting season is important. A short season can prevent a commercial hunting system from providing good, uncrowded hunting conditions and/or from obtaining an adequate kill. Lessors would have the option of putting too many hunters on their land at one time, or not getting an adequate harvest. The 9-day season presently in effect in South Dakota's West River Arca prohibits necessary flexibility. The length of the season is not a necessary factor in controlling the number of deer killed because this has already been accomplished by limiting the number of licenses. The length of hunting season was set in past years at the specific request of many ranchers, to keep the period of disturbance by hunters to a minimum. Many ranchers would still object to extending the hunting period.

Texas, where commercial hunting systems are prevalent, is divided into 11 hunting districts. Three of these have 16-day hunting seasons and the rest from 48 to 51 days (San Antonio Express/News, 1970). Texas ranchers, therefore, have the time during this long season necessary to manipulate various groups of hunters interested in different kinds of deer hunting, and can distribute the kill between areas and/ or between sexes as the situation warrants. For instance a rancher may restrict a group of hunters to a specific pasture for the first week of the season and specify only mature bucks be harvested. Later for another group of hunters more interested in venison than trophies, he might permit them to take a certain number of does. This of course can be done only in those areas where either sex is legal.

The Texas hunting lessor has an added advantage in that the yearly bag limit for deer is two, three, or four, depending on the district. It is obvious that hunting leases are more easily sold when the lessee has a chance to get more than one deer. Although South Dakota's prairie deer numbers could be increased substantially through habitat improvement programs, it is doubtful that numbers will ever allow more than one deer per hunter per season.

\section{Proximity of Public Land}

If some lands in public ownership (Forest Service, U.S. Department of Agriculture, and Bureau of Land Management, U.S. Department of the Interior) are close to private areas where a fee is charged, it is only natural to expect many hunters to choose the "free" area. The effects of proximity of public land on fee hunting systems will depend on the percent of the total area made up of public land and the number of hunters using that area. The demand for recreation on public lands is steadily increasing, however, and is becoming so intense that hunters, in particular, are more willing to invest some money for the sole purpose of getting away from the crowds. For example, the number of deer licenses sold in the Black Hills Unit, almost all of which is in the Black Hills National Forest, increased from 14,709 in 1964 to 26,538 in 1969 (J. Kranz, Research Biologist, personal communication). One rancher, whose land is within the Black Hills Unit, but on the northern edge of the
National Forest, reported no problem in obtaining hunters at a modest fee of $\$ 5$ per hunter per day. Comments from hunters indicated that control of the number of hunters allowed on the area was one of the main reasons they didn't mind paying a fee (H. Frawley, Jr., personal communication).

It is evident that a private landowner located in an area that is predominantly public land would have to provide services (guiding, packing, accommodations) other than just access if his operation is to succeed. On the other hand, a lack of public hunting areas combined with a large number of hunters, presents an optimum situation for the development of a fee hunting operation. Teer and Forrest (1968) attribute the early and successful growth of commercial hunting in Texas primarily to ". . . the virtual lack of public lands on which the public had free access to hunt."

One other factor that could influence the use of leasing systems is Recommendation 65 in the Public Land Law Review Commission Report (1970) which states "A Federal land use fee should be charged for hunting and fishing on all public lands open for such purposes." If implemented, this would tend to put commercial hunting systems on private lands on a more competitive basis with public lands.

\section{Hunter Demand and the Game Crop}

South Dakota simply doesn't have the demand (numbers of hunters) or the quantity (numbers of deer) that Texas has. Texas has a deer population estimated at about 3 million (Teer and Forrest, 1968) compared to about 250,000 in South Dakota. The total deer harvest in Texas was estimated at 239,000 in 1967 (Teer and Forrest, 1968); in the samc ycar 29,000 were killed in South Dakota (South Dakota Department of Game, Fish, and Parks, 1968).

Klussman (1966) analyzed data from 1965 and reported that 22 million acres were leased for hunt- 
ing by 13,000 landowners in Texas. Income from these leases amounted to $\$ 13$ million. Teer and Forrest (1968) thought these to be rough approximations, but indicated that hunting income was substantial in the state. Teer and Forrest (1968) reported that "on many ranches in the Edwards Plateau and Central Mineral region net returns from the salc of hunting rights cxceed the returns from the livestock enterprise on the same ranges."

The average South Dakota rancher will probably never realize such returns from leasing hunting rights. Only for those operations that are located in prime deer habitat, provide trophy hunting, and offer a maximum of services beyond access, will the potential income begin to compare with that in Texas. The potential for these operations is limited, primarily because of the uneven distribution of good deer habitat on the prairies of western South Dakota and the relatively light demand for extensive services.

\section{Attitudes of Landowners and Hunters}

The "average" South Dakota deer hunter is accustomed to free access for hunting and is not going to appreciate having to pay to hunt. Initially, almost all will be strongly opposed to programs of this type.

The task of convincing such hunters that a fee will result in a more favorable hunting experience will fall on none other than the landowners as a group. They must approach this task in two ways: 1) by initiating different kinds of hunting systems that could include hunters from all income groups and 2) by diverting some of the income derived from this source into planning and managing for the game crop.

Four basic types of leasing arrangements described by Teer and Forrest (1968) could be used by South Dakota landowners. In the outfitter system, several ranches may be leased to an outfitter who handles all the arrangements. Gen- erally, the services offered are extensive enough (food, lodging, guide services, care of game, and so forth) that prices are quite high $(\$ 50$ $\$ 70 /$ hunter/day). I'his is essentially the arrangement employed by $\mathrm{Da}$ kota Safaris. In the season-long lease system, a rancher or group of ranchers leases access rights to an individual or group who would then have exclusive hunting privileges for that season. This would be within reach of more of our resident hunters. The day-long lease allows hunters access to game on a per-day basis. Prices under this system would vary with local circumstances, but could be within reach of almost all South Dakota resident hunters. The fourth system involves charging directly for the animal; legal only if the rancher has purchased and/or raised the game animal. Texas ranches are importing and raising several species of exotic game animals such as mouflon, barbary sheep, and blackbuck. Because this requires considerable physical and monetary output by the rancher, costs to the hunter would be quite high. Advantages here are that a hunting license is not required and hunting seasons are generally much longer than they are for State-owned game, although the operator is required to have a shooting preserve license. Initial efforts have been made in this direction in South Dakota by raising and releasing pheasants, mallards, and bob-white quail.

It is important, if fee hunting is adopted over a large area involving many separate operations, that more than one of these systems be used. If all landowners implemented the outfitter system in South Dakota under the present nonresident restrictions, there wouldn't be enough hunters to go around. Those resident hunters unable to afford such accommodations could, as a group, force legislation to prohibit or impair development of hunting systems. Systems must be developed to meet all demands.

The landowner has another responsibility-to limit the number of hunters allowed on a tract of land to provide a safe, quality hunting experience.

All of these responsibilities, however important, assume secondary status when considering the landowner's attitudes toward management of the game crop. If the landowner is realizing an income from wildlife, he must express concern for this resource in his management plans. This point was emphasized by Teer and Forrest (1968) who stated, "Landowners merit an economic return for animals in which inputs of resources are made. We consider unethical those hunting programs in which management is only directed at attracting, holding, and concentrating game for harvest purposes." Concern for the wildlife resource must be a basic axiom for commercial hunting programs.

The term "management" here, specifically implies proper management. Onc problem regularly encountered with leasing systems in Texas is underharvest-not enough deer are killed (Ramsey, 1965; Teer et al., 1965; Teer and Forrest, 1968). Ranchers, hunters, and most others do not realize how many deer are present and how many can be harvested without damaging the herd. Apparently, as game becomes more valuable, landowncrs have a tendency to become more conservative in their allowed kill. With the resultant population buildup from repeated underharvests, the range resource will deteriorate just as it will from overgrazing with livestock. Overpopulations of deer become much more of a problem on haystacks, winter wheat, and alfalfa. Also, deer herds held on a lowquality diet contain fewer quality animals; they are generally smaller deer with poorer antler development. Harvest management should not be directed only at total deer removed, but should strive to achieve a proper ratio of does/ bucks taken. Sufficient harvest of does can become a real problem on ranches that stress only trophy buck hunting.

Wildlife habitat must also be 
managed. South Dakota ranchers do not have the forage competition problems so evident in Texas. In the Edwards Plateau and Llano Basin country, deer ranges are also used by cattle, horses, sheep, and goats (Teer et al., 1965). Northern Great Plains ranchers would be concerned primarily with integrating cattle range management with deer range management, although sheep and horses would be involved in a few cases. In many areas of the West, high-condition ranges may be optimum for cattle production, but slightly to moderately overgrazed ranges could enhance the area for wildlife (for a discussion of principles see p. 108-109, National Research Council, 1970). One of the reasons for this is that many of the shrubby plants, beneficial to wildlife for food and cover, respond as increasers on overgrazed cattle ranges. Although more studies are needed to determine the components of high-condition rangeland in the Northern Great Plains, particularly for wildlife, management goals for livestock and wildlife appear to be similar-toward high condition on most, if not all, range sites. Regardless whether management goals are for livestock or wildlife, some sacrifices and changes will probably have to be made when wildlife is to be integrated into an operation previously managed only for livestock. Landowners have a moral obligation to make such changes commensurate with the income they are receiving from the wildlife resource. Certainly, if a leasing system is successful the economic incentive would dictate such changes.

Cooperation between landowners and State game management agencies would be essential. Unethical operations could result in "backlash" legislation that would prevent the establishment, or at least hinder the development, of fee hunting programs. Commercial hunting operations need the support of the State so that appropriate regulations are developed that would encourage their stability and growth.

State game agencies also have the expertise to assist the landowner with wildlife management problems. It would behoove private land managers to seek this advice. Game biologists, when offering such advice, must realize that livestock grazing will still probably be the primary use of the unit, and wildlife management suggestions must be realistic and fit the economic structure of the overall operation.

Sportsmen must accept a basic fact: although State game and fish departments have control over game populations through harvest regulations, no one has control over the development of wildlife habitat on private lands except the landowner. There are, of course, some programs such as the Wildlife Habitat Improvement Program (WHIP), Cropland Adjustment Program (CAP) and others that allow for the development of wildlife habitat on private lands. However, these are voluntary and have had only limited success, primarily because of lack of interest on the part of the landowner.

The sportsman must realize that good wildlife management will be practiced on private lands only if the landowner develops an interest in wildlife and cooperates in its management. Presumably, if landowners realize an income from the wildlife resource, they will be more willing to consider that resource in their ranch management plans. Sportsmen should assist with monetary and other support for wildlife management on private lands if he is to participatc in the harvest, rather than expect the landowner to expend personal income to maintain and improve conditions for wildlife. A small investment by sportsmen could be repaid many fold in enhanced quantity and quality of hunting opportunities.

\section{Literature Cited}

Gartner, F. R., and K. E. Severson. 1972. Fee hunting in western South Dakota. J. Range Manage. 25:234237.

Klussman, W. G. 1966. Deer and the commercialized hunting system in Texas. Proceedings. The Whitetailed deer-its problems and potentials. Texas Agr. Ext. Serv., Texas A\&M, p. 18-21.

National Reseakch Council. 1970. Land use and wildlife resources. Comm. on Agr. Land Use and Wildlife Res., S. S. Atwood, Chairman, Nat. Acad. Sci., Washington, D.C. 262 p.

Public Land Law Review Commission. 1970. One third of the Nation's Land. U.S. Govt. Printing Office, Washington, D.C. 342 p.

Ramsey, C. W. 1965. Potential economic returns from deer as compared with livestock in the Edwards Plateau Region of Texas. J. Range Manage. 18:247-250.

SAN ANTonio Express/News. 1970. Deer, quail, turkey, javelina seasons. San Antonio, Texas, Oct. 25, p. 4-L. South Dakota Department of Game, Fish and Parks. 1968. South Dakota Conserv. Dig. Ann. Rep., S. Dak. Game, Fish and Parks Dep., Pierre, $32 \mathrm{p}$.

TeEr, J. G., AND N. K. Forrest. 1968. Bionomic and ethical implications of commercial game harvest programs. Trans. 33rd N. Amer. Wildlife Conf: 192-204.

Teer, J. G., J. W. Thomas, and E. A. WALKER. 1965. Ecology and management of the white-tailed deer in the Llano Basin of Texas. Wildlife Monogr. 15, $62 \mathrm{p}$.

U.S. Bureau of the Census. 1970. Statistical abstract of the United States 1970. (91st ed.). Washington D.C. 1018 p.

\section{SRM Annual Meetings}

February 4-9, 1973

Boise, Idaho.
February 3-8, 1974

Tucson, Arizona.
CLYDE ROBIN

NATIVE SEEDS

Castro Valley, California 94546 